\title{
Parameters for Dimensional Inspection of Orifice Plates and Roughness of the Straight Stretches of the Tubing
}

\author{
Alberto Kennedy de Almeida Medeiros ${ }^{1 *}$, Jeffersson Fernandes de Lima ${ }^{1}$, Gilson Gomes de \\ Medeiros $^{1,2}$, Nivaldo Ferreira da Silva Junior ${ }^{1}$, Raimundo Nonato B. Felipe ${ }^{1}$ and Renata \\ Carla Tavares dos Santos Felipe ${ }^{1}$ \\ ${ }^{1}$ Centro Federal de Educação Tecnológica do Rio Grande do Norte - CEFET-RN; Av. Sen. Salgado Filho, 1559; \\ Tirol; Natal - RN - Brasil. ${ }^{2}$ Universidade Federal do Rio Grande do Norte - UFRN/DEQ; Campus Universitário; \\ Natal - RN - Brasil
}

\begin{abstract}
According to the Technical Regulation of Measurement of Petroleum and Natural Gas (approved in 2000 by ANP the Petroleum National Agency of Brazil), the systems of measurement of natural gas should use ultra-sonic flow meters, turbines and, especially, the orifice plates, which represent the most expressive base of the flow systems, being used in the fiscal and operational measurements. This work aims to evaluate the parameters that should be accounted for during the dimensional inspection of orifice plate and roughness of the straight stretches of the tubing used for measurement of natural gas, with the objective of guiding the responsible professionals for the measurement of volumes of natural gas by orifice plate, as well as the professionals of calibration laboratories. In this work, minimum specifications are recommended, irrespective of the pressure tapping or orifice type, in agreement with the norms ISO, AGA and the ANP regulations. The influence of these specifications on the parameters used in the calculation of the volumetric flow is also analyzed.
\end{abstract}

Key words: Orifice plate, superficial roughness, measurement parameters

\section{INTRODUCTION}

In Brazil, the Technical Regulation of Measurement of Petroleum and Natural Gas RTM (PANP/INMETRO 1/2000, 2000) establishes the requirements that the systems of measurement of natural gas should contain in order to ensure an accurate and complete measurement.

Systems of natural gas flow measurement based on the orifice plate as primary element is used thoroughly in Brazil, in the fiscal and operational measurements of the gas. It is believed that, currently, about $80 \%$ to $85 \%$ of the systems are based on that element (Rosendo et al., 2003).

The fundament of the orifice plate operation consists of introducing a located restriction in the point where the measurement should be obtained. Such restriction changes the speed of the flow and causes a differential of pressures that is proportional to the fluid flow.

The objective of this work is to evaluate the parameters that should be accounted for during the dimensional inspection of orifice plate and of the roughness of the straight stretches of the tubing used for measurement of natural gas, with the purpose of guiding the professionals

\footnotetext{
* Author for correspondence
} 
responsible for the measurement of natural gas volumes by orifice plate, as well as professionals of calibration laboratories who issue calibration certificates, in agreement with the specifications described in the norms ISO 5167, 1991 and AGA Report no. 3, 1990.

\section{METHODOLOGY}

A theoretical study about the general description of natural gas measurers based on orifice plate and the straight stretches of the tubing has been accomplished. Several parameters influence on the pressure drop along the tubing, such as its length, the speed and the viscosity of the fluid that moves through the tubing and the attrition provoked by the roughness of the internal wall of the tubing.

The variables that are influenced by the constructive characteristics of the orifice plates were studied, setting tolerable minimum and maximum values for these components, aiming at obtaining the parameters of acceptance of plates submitted to the dimensional inspection and of the superficial roughness of the straight stretches of the tubing, as established in item 7.1.7 of the Technical Regulation of Measurement of
Petroleum and Natural Gas - RTM, above mentioned.

The whole study was developed based on the norms ISO 5167, 1991 and AGA no. 3, 1990 ,aiming at applying it to the procedure for dimensional inspection of orifice plate and of roughness of straight stretches of tubing in the petroleum industry whose purpose is the establishment of the reliability in the measurement of the natural gas.

The equation of the volumetric flow for subcritical drainings, used for the determination of the produced volume of natural gas (Rosendo et al., 2003), is shown below. The parameters of this equation are detailed in Table 1.

$$
Q v=\frac{\alpha \varepsilon F h a \sqrt{2 \rho_{1} \Delta P}}{\rho r}
$$

where:

$$
\begin{gathered}
\alpha=\frac{C}{\sqrt{1-\beta^{4}}} \\
\beta=\frac{d}{D} \\
a=\frac{\pi d^{2}}{4}
\end{gathered}
$$

Table 1 - Parameters used in the equation of the volumetric flow.

\begin{tabular}{cll}
\hline Symbols & \\
\hline $\mathrm{C}$ & Discharge Coefficient* \\
$\varepsilon$ & Factor of Expansion \\
$\mathrm{Fh}$ & Puncture of drain or respiration \\
$\beta(\mathrm{d} / \mathrm{D})$ & Relation between the diameter of the orifice and the diameter of the tube \\
$\alpha$ & Flow coefficient \\
$\mathrm{d}$ & Diameter of the Orifice $(\mathrm{m})$ \\
$\mathrm{D}$ & Diameter of the Tubing $(\mathrm{m})$ \\
$\mathrm{a}$ & Area of the orifice $\left(\mathrm{m}^{2}\right)$ \\
\hline
\end{tabular}

*Discharge coefficient for concentrical orifice plates with $\mathrm{D}<50 \mathrm{~mm}$.

It is known that the discharge coefficient is the relation between the real flow (with the measurer) and the theoretical flow (without the measurer). The discharge coefficient influences the flow coefficient $\alpha$ directly, as it is seen above in the shown equation (2), and it varies according to the profile of the velocity of the tubing, being calculated by the equation as follows:

$$
\begin{aligned}
& C=0.5959+0.0312 \beta^{2.1}+0.1840 \beta^{8} \\
& +0.0029 \beta^{2.5}\left[\frac{10^{6}}{\operatorname{Re}_{\mathrm{D}}}\right]
\end{aligned}
$$


Table 2 - Dimensional values of the system orifice plate/tubing.

\begin{tabular}{c|c|c|c} 
Sample & Orifice Diameter $(\mathbf{m m})$ & Tubing Diameter $(\mathbf{m m})$ & $\boldsymbol{\beta}(\mathbf{d} / \mathbf{D})$ \\
\hline AM-01 & 25 & 100 & 0.25 \\
AM-01 & 50 & 100 & 0.50 \\
AM-01 & 100 & 143 & 0.70 \\
\hline
\end{tabular}

Taking into consideration the equations 5 and 3 above, simulated calculations were accomplished to determine the influence of the dimensional tolerances of the orifice diameters on the discharge and flow coefficients from values of tubing and orifice diameters, and from the established $B$ in Table 2.

\section{RESULTS AND DISCUSSION}

The results of the studied parameters are presented as following.

\section{Internal Roughness of the Wall of the Tubing}

The internal roughness of the wall of the tubing influences on the discharge coefficient. As the roughness is not expressed in the calculation of the discharge coefficient, its limits are established so that the coefficients of discharge are contained in the uncertainty degree previously established, see Table 3 (Martins, 1998).

The values of the superficial roughness $k$, specified in units of length, depend on several factors, such as height, distribution, angularity and other geometric aspects of the elements of the roughness of the tube wall (ISO 5167, 1991).

The attrition losses depend on the diameter and extension of the tubing, the roughness of the walls, the viscosity of the fluid, the Reynolds number, the types and numbers of connections.

For the turbulent flows, the attrition factor is found in function of the Reynolds number.

The roughness increases with the use because of corrosion and incrustation.

The rate of this increasing depends on the material of the tubing and the fluid type.

Table 3 - Values of the equivalent superficial roughness k for each material type.

\begin{tabular}{c|cc}
\hline Material & Conditions & k (mm) \\
\hline Brass, copper, glass, aluminium, & Smooth and without sediments & $<0.03$ \\
& New without sewing & $<0.03$ \\
& New with sewing & $<0.10$ \\
Steel & Lightly rusty & 0.10 to 0.20 \\
& Incrusted & $<0.50$ to 2 \\
& Bituminized, new & 0.03 to 0.05 \\
& Bituminized, used & 0.10 to 0.20 \\
Cast iron & Galvanized & 0.13 \\
& New & 0.25 \\
& Rusty & 1.0 to 1.5 \\
\end{tabular}

*Data in agreement with the norm ISO 5167, 1991

The tubing with higher relative roughness can be used if the relative roughness is within the limits given above for at least 10D from the entrance face of the orifice plate (ISO 5167, 1991).

\section{Parameters for Dimensional Inspection of Orifice Plates}

For the analysis of dimensional inspection, it is recommended that the identification is visible after the installation of the plate in the line. This will usually be obtained through registration in the bolt (Martins, 1998; Delmée, 2003). Next , the parameters of manufacture of orifice plates, used as reference for the inspection and its respective analysis, will be presented.

\section{Upstream and downstream faces}

The upstream face will have to be plain. It will be considered plain when a straight line binding any two points of its surface has inferior inclination 
lower than $1 \%$. The upstream face must not present wire edges, burrs, risks or other imperfections (Delmée, 2003).

The downstream face, on the other hand, has to be parallel to the upstream face. There is no need to reach the same quality of state of the surface that is demanded for the upstream face. The flatness and the state will be judged by a simple visual examination.

\section{Roughness of the plate}

The plate can be manufactured with any material and any method, but in agreement with the norm specifications (Delmée, 2003).

The roughness of the upstream face of the orifice plate has to be inferior to $0.0001 \mathrm{~d}$, being determined in a concentrical circle to the orifice. The circle diameter not being inferior to $1.5 \mathrm{~d}$ as it is seen in the Fig. 1 (Martins, 1998).

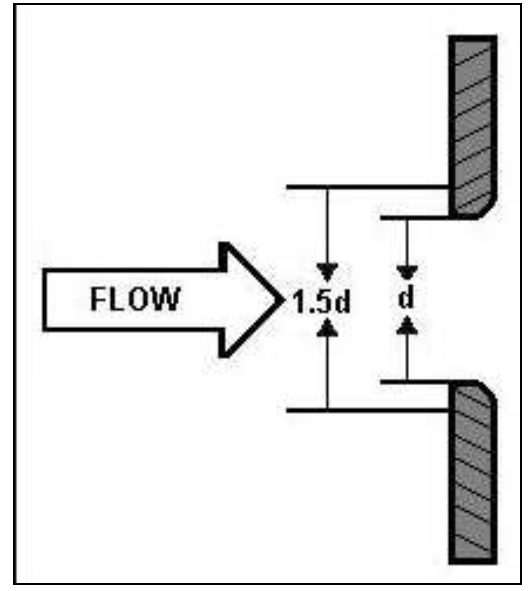

Figure 1 - Indication of the diameter $1.5 \mathrm{~d}$ to be considered for the determination of the roughness of the plate.

Table 4 - Allowed tolerance for orifice diameters.

\begin{tabular}{cc}
\hline Orifice diameter $(\mathbf{d}), \mathbf{m m}$ & Maximum deviation $(\%)$ \\
\hline $\mathrm{d} \leq 12$ & \pm 0.1 \\
$12<\mathrm{d} \leq 16$ & \pm 0.08 \\
$16<\mathrm{d} \leq 20$ & \pm 0.07 \\
$20<\mathrm{d} \leq 25$ & \pm 0.06 \\
$\mathrm{~d}>25$ & \pm 0.05 \\
\hline
\end{tabular}

\section{Orifice diameter (d)}

The orifice diameter $\mathrm{d}$ of the plate is given by the arithmetic mean of four or more measurements equally spaced in the perimeter of the orifice. None of these measurements differ from the value of the calculated diameter, nor from any another measured diameter beyond the limits shown in Table 4.

Diameter $\mathrm{d}$ is always limited among 0.1D and $0.8 \mathrm{D}$. However, to calculate the value of the orifice diameter of the plate, the reference diameter $\left(d_{r}\right)$ is determined, calculated to the reference temperature $\left(t_{r}\right)$ using the following equation (Araújo \& Link, 2004):

$$
d_{r}=d_{m}\left[1+\alpha_{1}\left(t_{r}-t_{m}\right)\right]
$$

where:

$\alpha_{1}=$ coefficient of linear expansion of the material of the plate;

$\mathrm{d}_{\mathrm{r}}=$ orifice diameter of the plate, calculated to the reference temperature $\left(t_{r}\right)$; $d_{m}=$ orifice diameter of the plate, measured to the temperature $t_{m}$;

$\mathrm{t}_{\mathrm{m}}=$ temperature of the plate during the measurements;

$t_{r}=$ reference temperature of the orifice plate.

Some maximum and minimum limits for respective orifice plate diameters $d(25,50$ and $100 \mathrm{~mm}$ ) have been simulated and are shown in Table 5.

\section{Entrance edge G}

The edge $G$ at the upstream should not show imperfections, burrs or visible peculiarities by rough estimate. It shall be sharp (Fig. 2). This will happen if the edge radius is not larger than $0.0004 d$.

For orifice plates with $\mathrm{d} \geq 25 \mathrm{~mm}$, only a visual inspection is enough. However, for $\mathrm{d}<25 \mathrm{~mm}$, this is not enough, but it can be considered satisfactory if the manufacturing of the face is sharp (Martins, 1998). 
Table 5 - Accepted tolerance for the orifice diameters of the samples.

\begin{tabular}{c|c|c}
\hline Samples & Orifice Diameter $(\mathbf{m m})$ & Tolerance $(\mathbf{m m})$ \\
\hline AM-01 & 25 & \pm 0.0125 \\
AM-02 & 50 & \pm 0.025 \\
AM-03 & 100 & \pm 0.05 \\
\hline
\end{tabular}

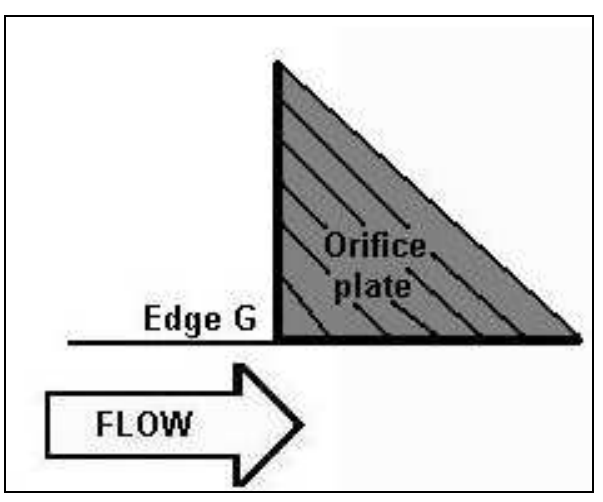

Figure 2 - Detail of the edge $\mathrm{G}$ of the orifice.

\section{Exit edges $H$ and $I$}

The edges $\mathrm{H}$ and I (Fig. 3) at the downstream are inside the region of exit of the flow. Therefore, the requirements for its quality are less rigorous than those for edge G; so, in this case, small defects are acceptable (Martins, 1998).

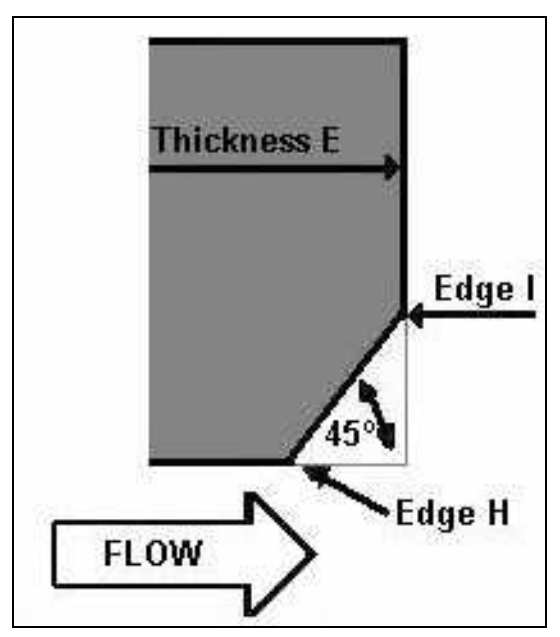

Figure 3 - Details of the edges H e I.

\section{Plate thickness E}

The plate thickness $\mathbf{E}$ should be kept among the orifice thickness e (see Fig. 4) and 0.05D. A careful attention should be paid so that the plastic or elastic deformation of the plate, due to the differential of pressures in operation, does not exceed the flatness limit that is specified by norm (Martins, 1998; Delmée, 2003).

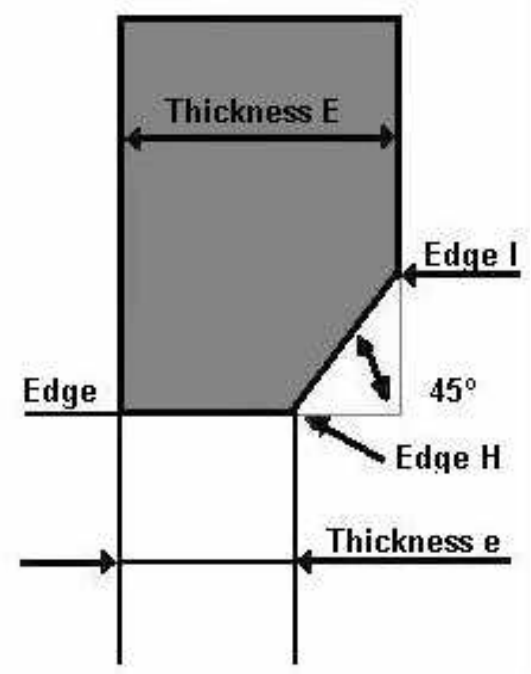

Figure 4 - Plate and orifice thicknesses.

\section{Verification of flatness}

The verification of flatness can be performed in a practical way, with the aid of a straight scale of approximately equal length to the internal diameter of the pipe, at the temperature of $20^{\circ} \mathrm{C}$ (Araújo \& Link, 2004), as it can be seen in Fig. 5. The allowed maximum deviation in the flatness can be determined by $0.005(\mathrm{D}-\mathrm{d})$.

The flatness can be found by the equation specified below.

$$
P=\frac{x+x^{l}}{D}
$$

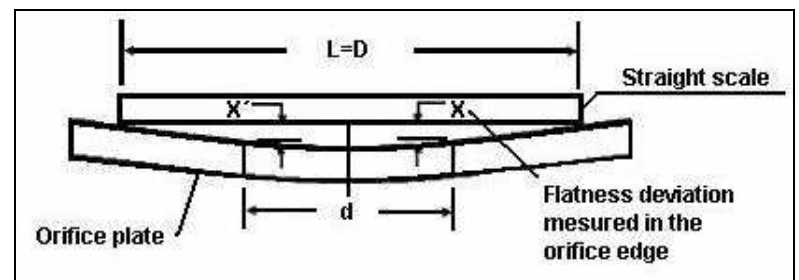

Figure 5 - Verification of flatness. 


\section{Angle of bevel}

When the plate thickness $\mathbf{E}$ is superior to the orifice thickness $\mathbf{e}$, the plate will have to be bevelled at the downstream edge (Fig. 6). The angle of bevel should range between 30 and $45^{\circ}$ (Martins, 1998).

The plate could not be bevelled if its thickness is inferior or equal to $0.02 \mathrm{D}$.

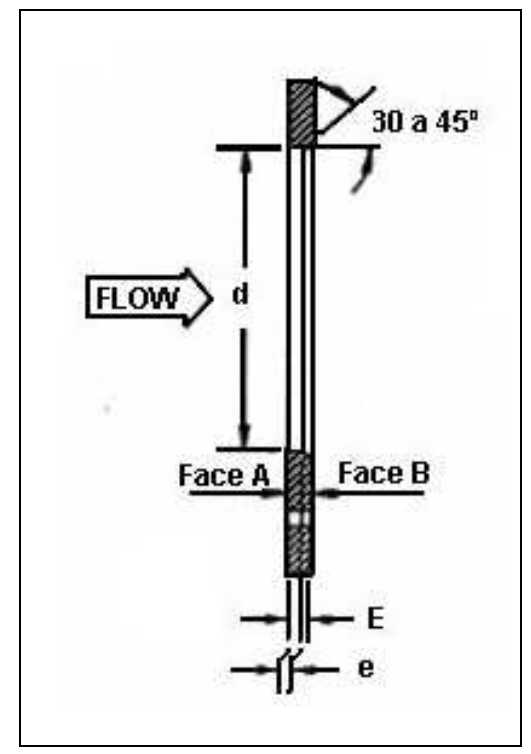

Figure 6 - Plate with bevel angle.

\section{Influence of the Established Tolerances on the Measurement Parameters}

The results demonstrate that the tolerances of the orifice plate diameters influence on the measurements of the discharge and flow coefficients. They are directly affected because, when the orifice diameter increases, a variation of the discharge, flow and $\beta$ coefficients occurs.

Some simulated calculations of the tolerances of the orifice diameters (d) were made, applying them to the determination of the influence of those tolerances on the measurements of the discharge, flow and $\beta$ coefficients, as shown in the Fig. 7, 8 and 9.

It was observed that the tolerance of the plate diameters causes a variation of $0.003 \%$ in the discharge coefficient for the sample AM-01. On the other hand, the sample AM-03 presented an increase of this variation of approximately $217 \%$ in relation to AM-02.

In Fig. 8, the influence of the flow coefficient on the determination of the volumetric flow can be observed, with a variation of $0.004 \%$ in the sample AM-01 and, for the sample AM- 02 , this variation is equal to $0.024 \%$. In the sample $\mathrm{AM}-03$, the variation is equal to $0.069 \%$, being thus evident that, the greater the orifice diameter (d), the greater the influence in the flow coefficient, thus influencing on the result of the general equation of the volumetric flow.

The coefficient $\beta$, that relates to the orifice and the tubing diameters, also is affected, as expected, for the dimensional tolerance of the orifice plate. This result can be seen in the Fig. 9, having a variation of $0.04 \%$ for more and less in sample AM-01, and an increment of this variation in about $50 \%$ for samples AM-02 and AM-03, becoming this coefficient the most affected by these tolerances.

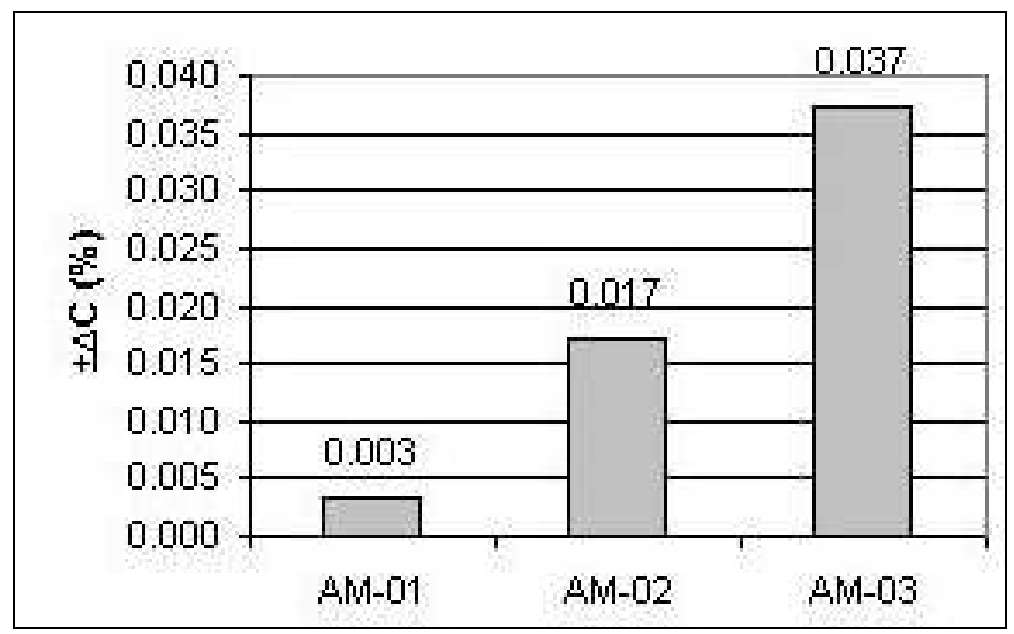

Figure 7 - Influence of the dimensional tolerance of the orifice diameter (d) in the discharge coefficient. 


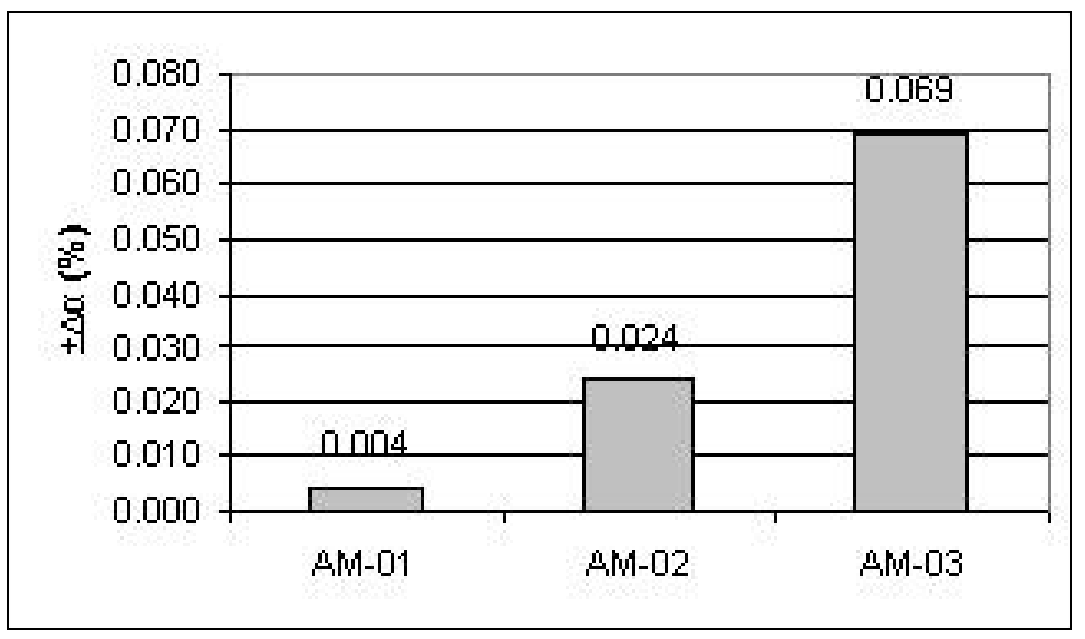

Figure 8 - Influence of the dimensional tolerance of the orifice diameter (d) in the flow coefficient.

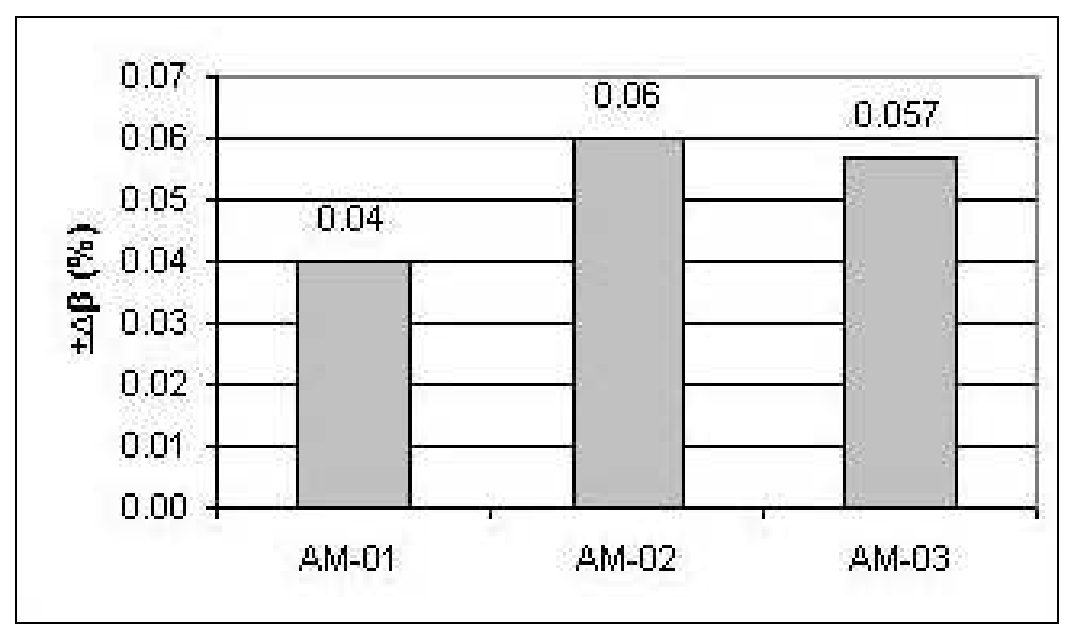

Figure 9 - Influence of the dimensional tolerance of the orifice diameter (d) in the $\beta$ coefficient.

\section{CONCLUSION}

In this work, the parameters for procedure of dimensional inspection of orifice plate and roughness of straight stretches of tubings have been shown.

On the basis of the simulated calculations, it can be concluded that the discharge, flow and $\beta$ coefficients, are directly influenced by the tolerance of the orifice diameter (d), thus affecting the general equation of the volumetric flow. Another important factor is the superficial roughness of the tubing, which increases with the use because of the corrosion and the incrustation in a rate that depends on the material of the tubing and the fluid.
From the studied parameters, it can be proven the importance of the dimensional inspection of orifice plates in the quality of the natural gas measurement carried through by the oil industry.

\section{ACKNOWLEDGMENTS}

This work was undertaken as part of the research project "Uncertainty of Measurement of Oil and Natural Gas", included in the Rede de Instrumentação e Controle (Rede 10/05). The authors are thankful to the Finep, CNPq and CENPES-Petrobras, for the financial support, which was essential for the its accomplishment. 


\section{RESUMO}

Segundo o Regulamento Técnico de Medição de Petróleo e Gás natural (aprovado em 2000), nos sistemas de medições de gás natural devem ser utilizados medidores de vazão tipo ultra-sônico, turbinas e, em especial, as placas de orifício, que representam a base mais expressiva do sistema de vazão, sendo empregadas nas medições fiscais e nas medições operacionais. Este trabalho tem como objetivo avaliar os parâmetros a serem considerados durante a inspeção dimensional de placa de orifício e da rugosidade dos trechos retos de tubulações usados para medição de gás natural, visando orientar os profissionais responsáveis pela medição de volume de gás natural por placa de orifício, como também a profissionais de laboratórios de calibração visando a emissão do certificado de calibração. No trabalho, são recomendadas especificações mínimas, independentemente do tipo de tomada ou de orifício, especificações estas descritas de acordo com as normas ISO 5167, AGA Report $\mathrm{N}^{\circ} 3$ e com a Portaria conjunta PAN/INMETRO No 1 de 19 de junho de 2000, como também analisa a influência destas especificações sobre os parâmetros usados no cálculo da vazão volumétrica.

\section{REFERENCES}

AGA Report n. 3, API 14.3, GPA 8185-90. (1990), Orifice metering of natural gas and other related hydrocarbons fluids - Part 1: General equation and uncertainty guidelines. American Gas Association. $3^{\text {rd }}$ ed. October, USA.

Araújo, L. P. and Link, W. (2004), Inspeção de placas de orifício. In: Workshop da Rede de Instrumentação e Controle, Natal. Anais... Natal - RN, 2004.

Delmée, G. J. (2003), Manual de medição de vazão. $3^{\circ}$ ed. São Paulo: Edgard Blücher.

ISO 5167-1. (1991), Measurement of fluid flow by means of pressure diferential devices - Part 1: Orifice plates, nozzles and venturi tubes inserted in circular cross-section conduits running full. International Organization for Standardization, Switzerland.

Martins, N. (1998), Manual de medição de vazão: através de placas de orifício, bocais e venturis. Rio de Janeiro: Interciência/Petrobras.

PANP/INMETRO 1/2000. (2000), Regulamento técnico de medição de petróleo e gás natural. Agência Nacional do Petróleo / Instituto Nacional de Metrologia Normalização e Qualidade Industrial INMETRO.
Rosendo, W.; Felipe, R. N. B.; Medeiros, G. G.; Felipe, R. C. T. S. and Silva Jr., N. F. (2003), Influência dos parâmetros da composição do gás natural na incerteza da medição do volume produzido. In: Congresso Nacional de Metrologia, Recife. Anais... Recife, Pernambuco.
Received: July 29, 2005; Revised: September 05, 2005; Accepted: November 22, 2005. 